\title{
Potentiometric Coated Wire Electrode for Salicylate based on Zinc(II) Acetylacetonate
}

\author{
M. Mazloum Ardakani, ${ }^{* a}$ P. Pourhakkak ${ }^{b}$ and M. Salavati-Niasari ${ }^{b}$ \\ ${ }^{a}$ Department of Chemistry, Faculty of Science, Yazd University, Yazd, Iran \\ ${ }^{b}$ Department of Chemistry, Faculty of Science, Kashan University, Kashan, Iran
}

\begin{abstract}
Um eletrodo na forma de fio modificado com acetilacetonato de zinco(II) como agente ionóforo, mostrou um comportamento de íon-seletivo exibindo uma resposta linear Nernstiana com uma inclinação igual a $-59.6 \pm 1.0 \mathrm{mV} /$ década para uma ampla faixa de concentração $(1.0$ $\left.\times 10^{-5}-1.0 \times 10^{-1} \mathrm{~mol} \mathrm{~L}^{-1}\right)$. O eletrodo apresentou um limite de detecção igual a $5.0 \times 10^{-6} \mathrm{~mol}$ $\mathrm{L}^{-1}$ e tempo de resposta entre 5 a $10 \mathrm{~s}$ para atingir um potencial estável de $95 \%$ em diferentes concentrações de salicilato. O eletrodo funciona adequadamente em soluções aquosas em uma faixa de $\mathrm{pH}$ de 2,7 a 7,8. A vida útil foi testada por dois meses a fim de investigar sua estabilidade e, durante esse período, não se observou alteração significativa. Contudo, após dois meses, a curva apresentou uma queda gradual. O eletrodo proposto apresentou uma alta seletividade ao salicilato em relação a anions inorgânicos e orgânicos comuns e foi aplicado com sucesso na determinação de salicilato em amostras de fármacos.
\end{abstract}

A coated-wire ion selective electrode based on zinc(II) acetylacetonate as ionophore exhibited linear response with Nernstian slope of $-59.6 \pm 1.0 \mathrm{mV} /$ decade over a wide concentration range $\left(1.0 \times 10^{-5}-1.0 \times 10^{-1} \mathrm{~mol} \mathrm{~L}^{-1}\right)$. This electrode has $5.0 \times 10^{-6} \mathrm{~mol} \mathrm{~L}-1$ detection limit. The proposed electrodes has a response time between $5-10 \mathrm{~s}$ to achieve a $95 \%$ steady potential for salicylate concentrations. The electrode was suitable for use in aqueous solutions in a wide $\mathrm{pH}$ range of 2.7 to 7.8. The electrode life time was tested over a period of two months to investigate its stability. No significant change in the performance of the electrode was observed during this period, but after two months, a gradual decrease ocurred in the slope. The proposed electrode showed high selectivity for salicylate over a number of common inorganic and organic anions. The electrode was successfully applied to the determination of salicylate in pharmaceutical samples.

Keywords: coated wire salicylate-selective electrode, salicylate, zinc(II) acetylacetonate

\section{Introduction}

Carrier-based ion-selective electrodes (ISEs) have found wide spread use for the direct determination of various ionic species in complex matrix samples. ${ }^{1,2}$ Their response characteristics, including: fast response time, wide linear, dynamic range, low detection limit and good selectivity make them suitable for direct and rapid analytical detection of trace amounts of chemically and biologically important compounds. Ion-selective electrodes based on polymer-coated membrane films directly on the surface of a conducting substance are very simple to construct and maintain since no filling solution is required and if the membrane is thin enough, such

*e-mail: mazloum@yazduni.ac.ir electrodes usually equilibrate much faster with the solution. ${ }^{3-6}$

Recently, ion-selective electrodes using poly(vinyl chloride) (PVC) membranes doped with organometallic ${ }^{7-9}$ species and a metal-ligand complex, including phtalocyanines, ${ }^{10,11}$ porphyrins, ${ }^{12,13}$ and metallocenes ${ }^{14}$ displayed potentiometric anion-selectivity sequence.

For the development of truly anion-selective electrodes, a strong interaction between the ionophore and the anions is required in order to complex anions in a selective fashion. Complexes of several central metal ions with different ligands have been reported to display such specific metal-ligand interactions and to induce anion selectivity of the membranes. Much research work on new ionophores for recognizing specific ions has been carried out in order to improve the potentiometric characteristics of the PVC membrane ISEs and to develop them for actual samples analysis. 
Salicylate and its derivatives, including acetylsalicylate $\left(\right.$ Aspirin $\left.{ }^{\circledR}\right)$, are commonly used as effective analgesics and are available in a wide variety of formulations. Aspirin, a prostaglandin biosynthesis inhibitor, is also an important antipyretic drug. Recently, a new therapeutic use has emerged based on an unique antiplatelet aggregation property, so that, aspirin is now being widely used to treat cardiovascular complications. ${ }^{15}$ Despite their utility as pain relievers and antipyretics, salicylates can be quite toxic if taken in large doses. Recommended therapeutic levels in plasma range from 0.15 to $2.1 \mathrm{mmol} \mathrm{L}^{-1}$ (total salicylate). Although, a large fraction of this total salicylate may be protein-bound. ${ }^{16,17}$ The most widely used analytical method for determining total salicylate is based on the Triender reaction, in witch a salicylate sample reacts with ferric ions to form a colored complex in acid solution. ${ }^{18}$ The main role of the present work was the development of a highly selective membrane electrode for salicylate based on PVC membranes containing zinc(II) acetylacetonate as ion carrier. The prepared membrane electrode displays a low detection limit and high sensitivity to salicylate determination and is promising for measurements of salicylate in drug samples.

\section{Experimental}

\section{Reagents}

Poly(vinyl chloride) (PVC) of high molecular weight was used as received from Fluka, bis (2-ethyl hexyl) phtalate (BEHP), trioctylmethylammoniumchloride (TOMACl), tetrahydrofuran, sodium salicylate and other chemicals were of the highest purity available from Merck and were used without further purification, except tetrahydrofuran (THF), which was distilled before use. All aqueous solutions were prepared with deionized and distilled water.

A stock solution of $0.1 \mathrm{~mol} \mathrm{~L}^{-1}$ salicylate was prepared by dissolving appropriate amounts of sodium salicylate in water. Solutions of anionic interferences, for selectivity studies, were prepared from sodium salts in water.

\section{Determination of salicylate in Aspirin ${ }^{\circledR}$ tablets}

Acetylsalicylic acid tablet samples (all purchased from local pharmacies) were finely powdered. A portion of the powder, equivalent to $500 \mathrm{mg}$ of acetyl salicylic acid, was prepared by directly dissolving the sample in $50 \mathrm{~mL}$ of 0.5 mol L-1 $\mathrm{NaOH}$. The mixture was heated over a boiling water bath for $1 \mathrm{~h}$. The resulting solution was diluted to $250 \mathrm{~mL}$ in a volumetric flask and used for the determination of salicylate content by potentiometric method. A $25 \mathrm{~mL}$ aliquot was employed for the salicylate determination by using the coated wire salicylate sensitive electrode at constant $\mathrm{pH}$. A standard addition method was employed to evaluate the concentration of salicylate. A standard procedure for the assay of soluble aspirin tablets was used as the reference method. ${ }^{19}$

\section{Preparation of zinc(II) acetylacetonate}

Zinc(II) acetylacetonate $\left[\mathrm{ZnL}_{2}\right]$, (Figure 1), was synthesized according to the Charles and Pawlikowsky method. ${ }^{20}$ The white product was recrystallized from chloroform and dried at $70{ }^{\circ} \mathrm{C}$ during several hours. Anal. Calc. for $\mathrm{C}_{10} \mathrm{H}_{14} \mathrm{O}_{4} \mathrm{Zn}$ : C, 45.56; H, 5.35; Zn, $24.81 \%$. Found: C, 45.41; H, 5.26; Zn, 24.62\%.

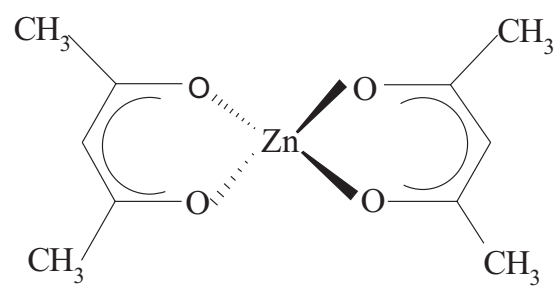

Figure 1. Structural representation of zinc(II) acetylacetonate used as ionophore in the CWSal-ISE.

\section{PVC membrane coated electrode}

The coated-wire salicylate ion-selective electrodes (CWSal-ISEs) were prepared according to a previously reported method. ${ }^{21-23}$ A mixture of PVC, plasticizer (BEHP), and the membrane additive (TOMACl), to give a total mass of $100 \mathrm{mg}$ was dissolved in about $5 \mathrm{~mL}$ of freshly distilled THF. The PVC-THF solution was mixed with bis(acetylacetonato) zinc(II). The resulting mixture was transferred into a glass dish. The solvent was slowly evaporated until an oily concentrated mixture was obtained. A platinum wire, about $1 \mathrm{~mm}$ diameter and $10 \mathrm{~mm}$ length, sealed into the end of a glass tube and soldered onto a shielded cable, was coated by repeated dipping in to the membrane solution in THF. The electrode ending part was dipped into the mixture for $\sim 5 \mathrm{~s}$, so that a nontransparent membrane of $\sim 0.3 \mathrm{~mm}$ thickness was formed and then, pulled out from the mixture and kept at room temperature for $1 \mathrm{~h}$. The prepared electrodes were finally conditioned by soaking in a $0.1 \mathrm{~mol} \mathrm{~L}^{-1}$ salicylate solution for $5 \mathrm{~h}$. The coating solutions were stable for several weeks, if kept in refrigerator and could be used for the construction of new membranes.

\section{Potential measurements}

The electromotive force (emf) values were read to the nearest $0.1 \mathrm{mV}$ with a $\mathrm{pH} / \mathrm{mV}$ meter "Metrohm" model 
691.The coated-wire electrode containing carrier was used as the measuring electrode in conjunction with double junction saturated calomel electrode (Metrohm). All measurements were preformed at ambient temperature $(25$ $\pm 1{ }^{\circ} \mathrm{C}$ ) using a $\mathrm{pH} / \mathrm{mV}$ meter (Metrohm, 691). The performance of each electrode was investigated by measuring its potential in solutions prepared the concentration range of $1.0 \times 10^{-7}-1.0 \times 10^{-1} \mathrm{~mol} \mathrm{~L}^{-1}$ by serial dilution at constant $\mathrm{pH}$. The sample solution $\mathrm{pH}$ was monitored simultaneously with a conventional glass $\mathrm{pH}$ electrode (Metrohm). The electrochemical cell (coatedwire) was:

\section{$\mathrm{Hg}, \mathrm{Hg}_{2} \mathrm{Cl}_{2}, \mathrm{KCl}$ (Sat.) || sample test | PVC | Pt}

The EMF readings were taken after the potential reached a constant value. The activity coefficients $(\gamma)$ were calculated according to the Debye-Hückel procedure. ${ }^{24}$ Also, for the calibration curve, concentration instead of activity was used. Potentiometric selectivity $\left(\mathrm{K}_{\mathrm{Sal}^{-}, \mathrm{A}^{-}}\right)$was determined by the fixed interference method (FIM).

\section{Results and Discussion}

The coated wire salicylate-electrodes based on the zinc(II) acetylacetonate as the carrier in plasticized PVC membrane were found to be highly responsive to salicylate ion relative to several other anions. The membrane without the ionophore displayed insignificant selectivity toward salicylate, whereas, in the presence of the ionophore, the membrane showed remarkable selectivity for salicylate over most common inorganic and organic anions. Therefore, we studied in detail the electrode performance for salicylate ion. In order to test the performance of the membrane characteristics, various operation parameters, such as, selectivity, response time, sensitivity, lifetime, working range of the electrode at different concentrations of the anion, $\mathrm{pH}$ and the effect of the membrane composition were investigated.

\section{Potentiometric response properties of salicylate electrodes}

As previously reported, the sensitivities and the selectivities obtained for a given ionophore were significantly dependent on the membrane ingredients and additives used. ${ }^{25}$ Polymer membrane gave an unique opportunity to obtain a variety of selective electrodes towards particular ions, by doping the membrane with certain ionophores. The response properties of membraneselective electrodes, based on ion carriers, are strongly influenced by the membrane composition, especially, ionic sites. ${ }^{26}$ Lipophilic ionic additive is a salt of nonexchangeable anion/cation and an exchangeable counter ion. Ionic sites provide electro-neutrality of the membrane with neutral ionic carriers, so that, no significant amount of counter ions can be co-extracted into the membrane together with the primary ion. Therefore, the membrane is permeable only for ions of the same charge sign as primary ion (Donnan exclusion) and demonstrates theoretical Nernstian response. Since the widely used uncharged carriers are neutral when uncomplexed and the complexes have the same charge as the analyte ion, the respective membranes require an additional incorporation of lipophilic ions of opposite charge to obtain a Nernstian response, a decrease in the membrane resistance, a reduction in the co-ion interferences, an improvement in the detection limit and a selectivity optimization. ${ }^{27-29}$ In practice, alkali salts of tetraphenylborate derivatives are used for cationic selective membranes and tetraalkylammonium salts for anion-selective membranes. The incorporation of ionic sites into the membrane is also beneficial for charged carrier based ISEs. Several membrane compositions were investigated by varying the proportions of PVC, BEHP, membrane active material, $\left[\mathrm{ZnL}_{2}\right]$ and TOMAC. Irrespective of the ionophore concentration, the slope was relatively larger when the BEHP/PVC weight ratio was approximately 2.0. It was also observed that the potentiometric response of the electrode toward salicylate ion depended on the concentration of the ionophore incorporated within the membrane. Increasing the amount of $\left[\mathrm{ZnL}_{2}\right]$ up to $5 \%$ resulted in membranes for which slopes were larger and the linear range wider.

The potentiometric response of the membrane was greatly improved by the presence of the lipophilic cationic additive, TOMAC. Better response characteristics, i.e. Nernstian response and improved selectivity, were usually observed with a TOMAC/ionophore weight ratio of approximately 0.1 , which corresponded to a mole ratio of approximately 0.15 .

Among the different compositions studied, the best response for the membrane was incorporating 33\% PVC, $61.5 \%$ BEHP, $0.5 \%$ additive and $5 \%\left[\mathrm{ZnL}_{2}\right]$. The

Table 1. Characteristics of optimized CWSal-ISE

\begin{tabular}{lc}
\hline Linear range/mol L-1 & $1.0 \times 10^{-5}-1.0 \times 10^{-1}$ \\
Slope/mVdecade ${ }^{-1}$ & -59.6 \\
$\mathrm{pH}$ range & $2.7-7.8$ \\
Precision & at concentrations of $1.0 \times 10^{-3}$ and \\
& $1.0 \times 10^{-4} \mathrm{~mol} \mathrm{~L}^{-1} \mathrm{Sal}^{-}$standard deviations \\
& were of \pm 0.75 and $\pm 0.90 \mathrm{mV}$ respectively \\
Detection limit/mol L & $5.0 \times 10^{-6}$ \\
Lifetime/month & 2 \\
Response time/s & $5-10$ \\
\hline
\end{tabular}




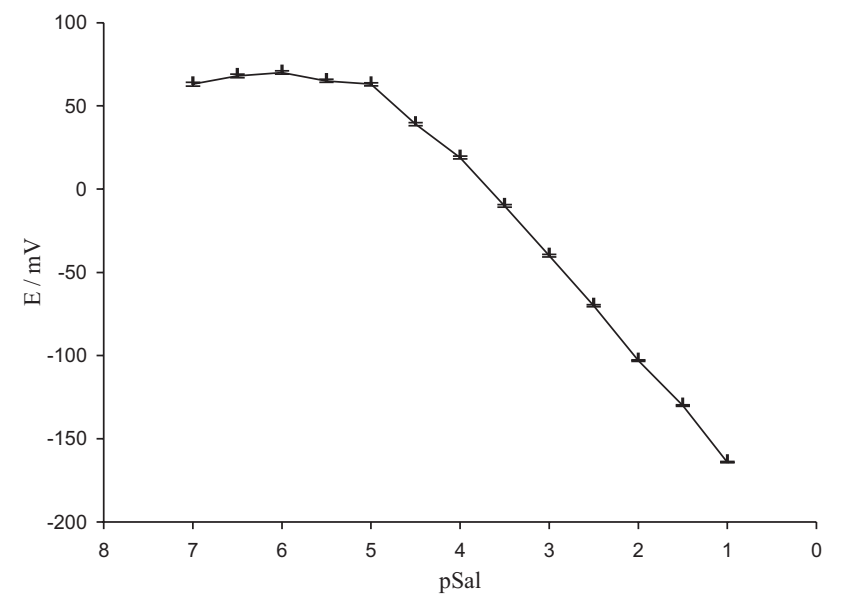

Figure 2. Potentiometric response of the ion-selective electrode based on zinc(II) acetylacetonate towards salicylate anion.

composition was, therefore, used to study the performance of the electrode, namely, working concentration range, sensitivity, selectivity, life time, response time and $\mathrm{pH}$ effect. The characteristic properties of the optimized membrane are summarized in Table 1 .

\section{Response characteristics of the electrode}

The potential response of the membrane electrode to varying concentrations of salicylate was examined over the concentration range $1.0 \times 10^{-7}-1.0 \times 10^{-1} \mathrm{~mol} \mathrm{~L}^{-1}$ using the optimized membrane composition and conditions described above. A typical calibration plot is shown in Figure 2, which depicts a linear range from $1.0 \times 10^{-5}-1.0$ $\times 10^{-1} \mathrm{~mol} \mathrm{~L}^{-1}$ with a Nernstian slope of $-59.6 \mathrm{mV}$ per decade. The practical limit of detection, taken as the concentration of salicylate at the point of intersection of the extrapolated linear segments of the calibration plot, was $5.0 \times 10^{-6} \mathrm{~mol} \mathrm{~L}^{-1}$.

The optimum equilibration time for the membrane electrode in the presence of $1.0 \times 10^{-3} \mathrm{~mol} \mathrm{~L}^{-1}$ sodium salicylate was $5 \mathrm{~h}$, after which it would generate stable potentials in contact with salicylate solution. The potentiometric response of the membrane electrode at different equilibrium times was examined using the optimized membrane composition and conditions described above.

The response time of electrochemical cells containing ion-selective electrodes is considered to be one of the most critical and limiting factors in the clinical and physiological applications of potentiometric sensors. Response times inherent to ion-selective electrodes are only measurable if the overall response time of the potentiometric system is governed by the properties of the membrane electrode, i.e., if the time constant of the electrode response function is much larger than the time constant of the electrochemical cell and the electronic EMF-measuring device. Indeed, the overall response time is affected by a series of factors, for example: the time constant of the measuring instrument, the impedance of the equivalent electrical circuit of the membrane, the rate of the ion-transfer reaction across the membrane/sample interface, the diffusion of the ion to be measured through the stagnant layer in the sample and establishment of a liquid-junction potential at the reference electrode..$^{30}$

The average time for the salicylate-selective electrode to reach a potential within $\pm 1 \mathrm{mV}$ of the final equilibrium value after successive immersion of the electrode in a series of salicylate ion solutions, each having a 10-fold difference in concentration, was measured. The static response time thus obtained was less than $10 \mathrm{~s}$ over the entire concentration range of $1.0 \times 10^{-5}-1.0 \times 10^{-1} \mathrm{~mol} \mathrm{~L}^{-1}$ of salicylate solution at $2.7-7.8 \mathrm{pH}$.

The stability and the reproducibility of the electrodes were also tested. The standard deviation of 15 replicates measurements at $1.0 \times 10^{-4}$ and $1.0 \times 10^{-3} \mathrm{~mol} \mathrm{~L}^{-1}$ salicylate concentrations were \pm 0.90 , and $\pm 0.75 \mathrm{mV}$. The detection system is very stable and can be used over a period of 2 months without observing a considerable change in their response characteristics.

The electrode lifetime was determined by recording its potential at an optimum $\mathrm{pH}$ value and plotting its calibration curve each day. It was observed that there was no significant change in the slope of the electrode on the following day. The electrode stability was tested over a 2-month period and during the test, the electrode was daily used.

The $\mathrm{pH}$ effect of the test solution on the response of the membrane electrodes was examined after conditioning in two concentrations of $1.0 \times 10^{-3} \mathrm{~mol} \mathrm{~L}^{-1}$ and $1.0 \times 10^{-3}$ mol L-1 sodium salicylate solution. The electrode response has no significant changes at $\mathrm{pH}$ 2.7-7.8 (Figure 3). The electrode behavior at high $\mathrm{pH}$ can be explained in terms of the increased interference from hydroxide ions. Protonation of salicylate anion may be the reason for the potential changes at low $\mathrm{pH}$ values.

\section{Interference studies}

Selectivity is the most important characteristic of an ion-selective electrode (ISE) membrane and explains its specificity towards a primary ion in the presence of interfering ions. For polymer membranes, interferences by other sample ions are mainly dictated by their competitive extraction into the membrane phase. Consequently, the ISEs response can be fully predicted 


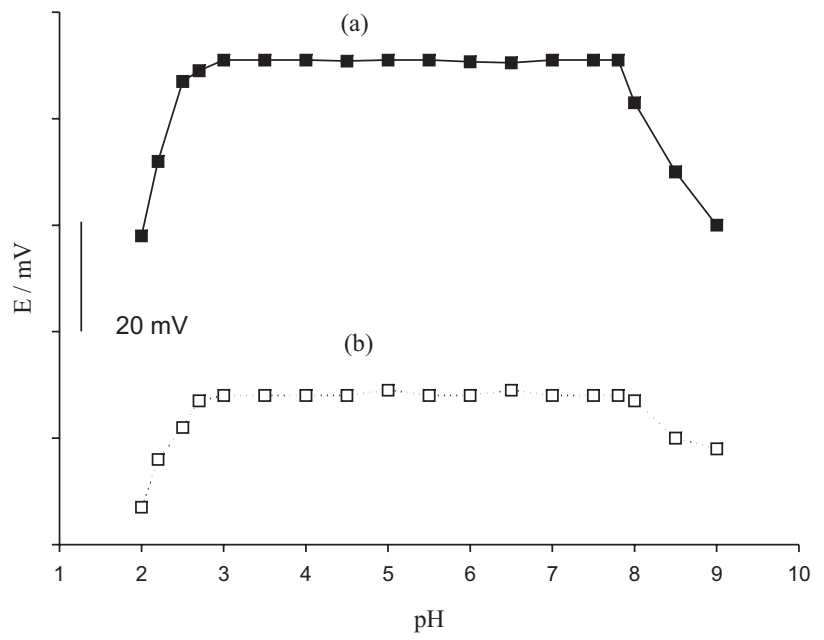

Figure 3.The influence of $\mathrm{pH}$ on the potential response of the optimized CWSal-ISE for (a) $1.0 \times 10^{-3} \mathrm{~mol} \mathrm{~L}^{-1}$ and (b) $1.0 \times 10^{-2} \mathrm{~mol} \mathrm{~L}^{-1}$ salicylate concentrations.

from thermodynamic constants, ionophore and ionic sites concentrations and, in the case of ionophore-based membranes, from the complex formation constants of each ion-ionophore complex in the membrane.

Concentrations were used rather than activities due to uncertainties in estimating the ionic strength of the background electrolyte.

The potentiometric ion selectivity coefficients of different electrodes, based on zinc(II) acetylacetonate membrane, are summarized in Table 2. The selectivity coefficient patterns clearly indicated that the electrode was highly selective to salicylate over a number of other anions (Table 2).

Potentiometric selectivity coefficients $\left(\mathrm{K}^{\mathrm{pot}}{ }_{\mathrm{Sal}^{-}, \mathrm{A}^{-}}\right)$ were determined by two methods: the fixed interference method (FIM) and the fixed primary method (FPM). The selectivity coefficient for various anions was evaluated by the mixed solution method with a fixed concentration of interference $\left(0.10 \mathrm{~mol} \mathrm{~L}^{-1}\right)$ and varying amounts of salicylate concentrations (FIM). The potentiometric selectivity coefficients were also evaluated by the fixed primary ion method from potential measurement on solutions containing a fixed amount of salicylate $\left(1.0 \times 10^{-3} \mathrm{~mol} \mathrm{~L}^{-1}\right)$ and varying amounts of the interfering ions (FPM). The selectivity coefficients clearly indicated that the electrode was selective to salicylate over a number of other inorganic and organic anions.

$\left[\mathrm{ZnL}_{2}\right]$ compound seemed to have higher interaction with the salicylate than any of the remainder anion tested. It is interesting to note that the observed selectivity pattern for the CWSal-ISE differs significantly from the so-called Hofmeister selectivity sequence. The ion interfering effect found follows the order:

$\mathrm{ClO}_{4}^{-}>\mathrm{I}^{-}>\mathrm{Cr}_{2} \mathrm{O}_{7}{ }^{2-}>\mathrm{Br}^{-}>\mathrm{NO}_{3}>\mathrm{CO}_{3}{ }^{2-}>\mathrm{OAc}^{-}=\mathrm{HCO}_{3}^{-}>$ $\mathrm{C}_{2} \mathrm{O}_{4}{ }^{2-}=\mathrm{NO}_{2}>\mathrm{Cl}^{-}>\mathrm{S}_{2} \mathrm{O}_{3}{ }^{2-}>\mathrm{SO}_{4}{ }^{2-}>\mathrm{CN}^{-}>\mathrm{PO}_{4}{ }^{3-}$

The sequence is characterized by the Hofmeister series:

$\mathrm{R}^{-}>\mathrm{ClO}_{4}^{-}>\mathrm{SCN}^{-}>\mathrm{I}^{-}>\mathrm{NO}_{3}^{-}>\mathrm{Cl}^{-}>\mathrm{HCO}_{3}^{-}>\mathrm{SO}_{4}^{2-}>$ $\mathrm{HPO}_{4}^{2-}$

The electrode selectivity coefficients do not comply with the Hofmeister series but show a selectivity which is close to it. However, the anion lipophilicity still plays an important role and only the simultaneous consideration of both the lipophilicity and the anion interaction with $\mathrm{Zn}$ allows one to explain the selectivity patterns. ${ }^{31}$

Table 3 lists the linear range, the detection limit, the slope, the response time and the selectivity coefficients of some of other salicylate-selective electrodes against proposed salicylate-selective electrode for comparative purposes. ${ }^{13,32-}$ ${ }^{35}$ It is noteworthy that the limit of detection, the linear range, the slope and the response time of the proposed electrode are also considerably improved with respect to those of the salicylate-selective electrodes previously reported.

\section{Analytical application}

The CWSal-ISE was also successfully used as an indicator electrode in conjunction with SCE in the

Table 2. Selectivity coefficients for the coated wire salicylate-selective electrode determined by the fixed interference method (FIM) and the fixed primary ion (FPM)

\begin{tabular}{|c|c|c|c|c|c|}
\hline Interference ion & $\log \mathrm{K}_{\mathrm{Sal}^{-}{ }^{\mathrm{pot}} \mathrm{A}^{-}(\mathrm{FIM})}$ & $\log \mathrm{K}_{\mathrm{Sal}^{-}, \mathrm{A}^{\mathrm{pot}}-(\mathrm{FPM})}$ & Interference ion & $\log \mathrm{K}_{\mathrm{Sal}^{-}{ }^{\mathrm{pot}} \mathrm{A}^{-}}^{-}(\mathrm{FIM})$ & $\log \mathrm{K}_{\mathrm{Sal}^{\mathrm{pot}}, \mathrm{A}^{-}}(\mathrm{FPM})$ \\
\hline $\mathrm{I}^{-}$ & -0.42 & -0.7 & $\mathrm{SO}_{4}^{2-}$ & -3.3 & -3.8 \\
\hline $\mathrm{CN}^{-}$ & -3.4 & -4.3 & $\mathrm{~S}_{2} \mathrm{O}_{3}^{4-}$ & -3.2 & -3.4 \\
\hline $\mathrm{Br}^{-}$ & -2.0 & -2.5 & $\mathrm{ClO}_{4}^{-}$ & -0.3 & -0.2 \\
\hline $\mathrm{Cr}_{2} \mathrm{O}_{7}^{2-}$ & -1.7 & -1.5 & $\mathrm{HCO}_{3}^{-}$ & -2.4 & -2.1 \\
\hline $\mathrm{OAc}^{-}$ & -2.3 & -2.9 & $\mathrm{NO}_{2}^{-}$ & -2.5 & -2.7 \\
\hline $\mathrm{NO}_{3}^{-}$ & -2.4 & -2.4 & $\mathrm{PO}_{4}^{2-}$ & -3.7 & -4.0 \\
\hline $\mathrm{CO}_{3}^{3-}$ & -2.2 & -2.1 & $\mathrm{C}_{2} \mathrm{O}_{4}^{4-}$ & -2.5 & -2.5 \\
\hline $\mathrm{Cl}^{-}$ & -2.7 & -3.3 & $-2=4$ & - & \\
\hline
\end{tabular}


Table 3. Comparison of the potentiometric parameters of the proposed CWSal-selective electrode with the other Sal-selective electrodes

\begin{tabular}{|c|c|c|c|c|c|c|}
\hline $\mathrm{A}^{-}$ & The proposed Sal-ISE & Ref.13 & Ref.32 & Ref.33 & Ref.34 & Ref.35 \\
\hline Nernstian slope/(mV/decade) & $-59.6 \pm 1.0$ & -55 & $-60.0 \pm 2$ & $\begin{array}{l}\text { Ionophores } \\
(\mathrm{I}, \mathrm{II} \text { respectively })^{\mathrm{a}} \\
-58.9,-59.0\end{array}$ & $\begin{array}{l}\text { Ionophores } \\
\begin{array}{l}(\mathrm{I}, \mathrm{II}, \mathrm{III}, \mathrm{IV}, \mathrm{V} \text { respectively })^{\mathrm{b}} \\
-50 \pm 2,-54 \pm 1 \\
-53 \pm 2,-41 \pm 1 \\
-41 \pm 1\end{array}\end{array}$ & $-62.0 \pm 1.2$ \\
\hline Linear range $/\left(\mathrm{mol} \mathrm{L}^{-1}\right)$ & $1.0 \times 10^{-5}-1.0 \times 10^{-1}$ & $\begin{array}{l}1.0 \times 10^{-5}- \\
1 \times 10^{-1}\end{array}$ & $\begin{array}{l}1 \times 10^{-3}- \\
1 \times 10^{-1}\end{array}$ & $\begin{array}{l}\text { Ionophores } \\
\text { (I,II,respectively) } \\
1.0 \times 10^{-6}-1.0 \times 10^{-1} \\
1.0 \times 10^{-5}-1.0 \times 10^{-1}\end{array}$ & $\begin{array}{l}\left(2.5 \times 10^{-4}-1 \times 10^{-1}\right) \\
\left(1 \times 10^{-4}-1 \times 10^{-1}\right) \\
\left(8 \times 10^{-5}-1 \times 10^{-1}\right) \\
\left(3 \times 10^{-4}-1 \times 10^{-1}\right) \\
\left(3 \times 10^{-4}-1 \times 10^{-1}\right)\end{array}$ & $6.0 \times 10^{-6}-1.0 \times 10^{-1}$ \\
\hline Limit of detection/(mol L-1) & $5.0 \times 10^{-6}$ & $1.0 \times 10^{-5}$ & $6.0 \times 10^{-4}$ & $\begin{array}{l}\text { Ionophores } \\
\text { (I,II, respectively) } \\
1.0 \times 10^{-6}-4.0 \times 10^{-6}\end{array}$ & $\begin{array}{l}8.0 \times 10^{-5}, 4.0 \times 10^{-5}, \\
1.3 \times 10^{-5}, 8.0 \times 10^{-5}, \\
8.0 \times 10^{-5}\end{array}$ & $1.0 \times 10^{-6}$ \\
\hline Response time/s & $5-10$ & $120-1200$ & $30-300$ & $20-30$ & - & $\sim 30$ \\
\hline Interferent ions & $\left(\mathrm{ClO}_{4}^{-}, \mathrm{I}^{-}, \mathrm{Cr}_{2} \mathrm{O}_{7}^{2-}\right)$ & $\mathrm{IO}_{4}^{-}, \mathrm{I}^{-}$ & $\mathrm{I}^{-}$ & Ionophores & - & \\
\hline $\mathrm{K}_{\mathrm{Sal}^{-}, \mathrm{A}^{\mathrm{pot}}}^{->} 1.0 \times 10^{-2}$ & & $\begin{array}{l}\mathrm{SCN}^{-} \\
\mathrm{ClO}_{4}^{-} \\
\mathrm{Br}^{-}\end{array}$ & Benzoate & $\begin{array}{l}(\mathrm{I}, \mathrm{II}, \mathrm{respectively}) \\
\left(\mathrm{ClO}_{4}^{-}, \mathrm{I}^{-}, \mathrm{SCN}^{-}, \mathrm{OH}^{-}\right) \\
\left(\mathrm{SCN}^{-}, \mathrm{OH}^{-}\right)\end{array}$ & $\begin{array}{l}\mathrm{ClO}_{4}^{-}, \mathrm{SCN}^{-}, \mathrm{I}^{-} \\
\mathrm{ClO}_{4}^{-} \mathrm{ClO}_{4}^{-} \mathrm{ClO}_{4}^{-} \\
\mathrm{SCN}^{-}\end{array}$ & $\begin{array}{l}\mathrm{I}^{-}, \\
\mathrm{ClO}_{4}^{-}, \mathrm{SCN}^{-}\end{array}$ \\
\hline $\mathrm{pH}$ range & $2.7-7.8$ & $5.5-7.2$ & $4.0-9.5$ & $3.0-8.0$ & $6.0-10.0$ & $4.0-6.0$ \\
\hline
\end{tabular}

${ }^{\mathrm{a}}$ Ionophore I and II are [Al (salophen)] and [Sn (salophen)], respectively; ${ }^{\mathrm{b}}$ Ionophore I, II, III, IV and V are [Aluminum Tetrakis-tert-butylphthalocyanine Chloride (PæAlCl), PæCu, PæSnCl 2 , PæLuOAc, PæDyOAc] respectively. Tetrakis-tert-butylphthalocyanine=Pæ.

Table 4. Determination of salicylate in different Aspirin ${ }^{\circledR}$ tablet samples $(\mathrm{n}=10)$

\begin{tabular}{lrrr}
\hline $\begin{array}{l}\text { Aspirin } \\
\text { samples } \\
\text { (mg/Tablet) }\end{array}$ & $\begin{array}{c}\text { Spectrophotometric } \\
\text { method }\end{array}$ & CWISE & $\begin{array}{c}\text { Percentage of difference } \\
\text { between results }\end{array}$ \\
\hline 100 & $95.2 \pm 0.6$ & $91.0 \pm 1.0$ & $4.4 \%$ \\
325 & $311.0 \pm 0.8$ & $311.0 \pm 1.0$ & $0 \%$ \\
500 & $478.0 \pm 1.1$ & $472.0 \pm 2.0$ & $1.2 \%$ \\
\hline
\end{tabular}

Table 5. Recovery of salicylate added to the human urine samples

\begin{tabular}{lcc}
\hline $\begin{array}{l}\text { salicylate added/ } \\
\left(\mathrm{mmol} \mathrm{L}^{-1}\right)\end{array}$ & $\begin{array}{c}\text { salicylate found/ } \\
\left(\mathrm{mmol} \mathrm{L}^{-1}\right)\end{array}$ & $\begin{array}{c}\text { average recovery } \\
(\%)\end{array}$ \\
\hline 0.00 & 0.32 & - \\
0.86 & 1.16 & 98.3 \\
1.42 & 1.79 & 103 \\
2.10 & 2.35 & 97.1 \\
\hline
\end{tabular}

potentiometric titration of sodium salicylate solution with $\mathrm{Cu}\left(\mathrm{NO}_{3}\right)_{2}$ as a suitable titrant.

It is known that the salicylate and its derivatives are extensively used as analgetics in many pharmaceutical preparations. Evidently, acetylsalicylic acid is the most widespread due to the high Aspirin ${ }^{\circledR}$ prescription over the world. The proposed electrode was used for the salicylate content determination of the different hydrolyzed pharmaceutical preparations. Aspirin ${ }^{\circledR}$ tablets of different samples were treated according to the procedure described before and the resulting solutions were used for the salicylate content determination using potentiometric method. The results are compared with the standard spectrophotometric method. ${ }^{19}$ The results obtained by the membrane electrodes (Table 4) were in good agreement with the procedures and the labeled colorimetric results.

As shown in Table 5, the quality of the results was evaluated by performing a recovery test, spiking the urine sample with standard salicylate solution. The recoveries for $0.86,1.42$ and $2.10 \mathrm{mmol} \mathrm{L}^{-1}$ of salicylate added to the sample were $98.3,103$ and $97.1 \%$, respectively.

\section{Conclusions}

The membrane CWSal-selective electrode, prepared with zinc(II) acetylacetonate under optimal PVCmembrane ingredients revealed a Nernstian response over a wide salicylate concentration range, fast response time, reproducibility and long lifetime. The present CWSal-selective electrode displayed very good selectivity for salicylate ion with respect to $\mathrm{NO}_{3}^{-}, \mathrm{I}^{-}$ and other ions. The electrode was used as an indicator electrode for determination of $\mathrm{Sal}^{-}$solution with $\mathrm{Cu}^{2+}$ solution. The membrane electrode was successfully applied for the salicylate content determination in pharmaceuticals samples. The high salicylate selectivity degree of the electrode makes it potentially useful for monitoring concentration levels of salicylate in drug samples. 


\section{Acknowledgment}

The authors express their appreciation to the University of Kashan Research Council, IUT Research Council and Center of Excellence in Sensors for support of this work.

\section{References}

1. Bakker, E.; Buhlmann, P.; Pretsch, E.; Chem. Rev. 1997, 97, 3083.

2. Buhlmann, P.; Pretsch, E.; Bakker, E.; Chem. Rev. 1998, 98, 1593.

3. Mazloum, M.; Salavati Niassary, M.; Amini, M. K.; Sens. Actuators B 2002, 82, 259.

4. Catrall, R.W.; Chin-Pohpui; Anal. Chem. 1976, 48, 552.

5. Khalil, S.; Analyst 1999, 124, 139.

6. Missel, P. J.; Langmuir, 1999, 15, 7122.

7. Wuthier, U.; Pham, H. V.; Zund, R.; Welti, D.; Funk, R.J.J.; Bezegh, A.; Ammann, D.; Pretsch, E. Simon, W.; Anal. Chem. 1984, 56, 535.

8. Schulthess, P.; Ammann, D.; Krautler, B.; Caderas, C.; Stepanek, R.; Simon, W.; Anal. Chem. 1985, 57, 1397.

9. Schulthess, P.; Ammann, D.; Simon, W.; Caderas, C.; Stepanek, R.; Krautler, B.; Helv. Chim. Acta 1984, 67, 1026.

10. Li, J. Z.; Wu, X. C.; Yuan, R.; Lin, H. G.; Yu, R. Q.; Analyst 1994, 119, 1363.

11. Nakamura, T.; Hayashi, C.; Ogawara, T.; Bull. Chem. Soc. Jpn. 1996, 69, 1555.

12. Bakker, E.; Malinowska, E.; Schiller, R. D.; Mayerhoff, M. E.; Talanta 1994, 41, 881.

13. Chaniotakis, N. A.; Park, S. B.; Mayerhoff, M. E.; Anal. Chem. 1989, 61, 566.

14. Hisamoto, H.; Siswanta, D.; Nishihara, H. Suzuki, K.; Anal. Chim. Acta 1995, 304,171.

15. Sanyal, A. K.; Dutta, A.; J. AOAC Int. 1996, 79, 1303.

16. Stewart, M. S.; Watson, I. D.; Ann. Clin. Biochem. 1987, 24, 552.
17. Smith, M. J. H.; Smith, P. K.; The Salicylates, A Critical Bibliographic Review, Interscience: New York, 1966.

18. Trinder, P.; Biochem. J. 1954, 57, 301.

19. British Pharmacopeia, Her Majesty's Stationery Office, Vol. 2, pp. 733-736, London, 1980.

20. Charles, R. G.; Pawlikowsky, M. A.; J. Phys. Chem. 1958, 62, 440.

21. Amini, M. K.; Mazloum, M.; Ensafi, A. A.; Fresenius J Anal Chem. 1999, 364, 690.

22. Mazloum, M.; Amini, M. K.; Mohammadpour-Baltork, I.; Sens. Actuators B 2000, 63, 80 .

23. Firooz, A. R.; Mazloum, M.; Safari, J.; Amini, M. K.; Anal. Bioanal. Chem. 2002, 372, 718.

24. Kamata, S.; Bhal, A.; Fakunaga, Y.; Marata, A.; Anal. Chem. 1998, 60, 2464.

25. Hauser, C. P.; Anal. Chim. Acta 1993, 278, 227.

26. Bakker, E.; Bühlmann, P.; Pretsch, E.; Electroanalysis 1999, 11, 915 .

27. Bühlmann, P.; Yajima, S.; Tohda, K.; Umezawa, Y.; Electrochim. Acta 1995, 40, 3021.

28. Eugster, R.; Gehrig, P. M.; Morf, W. E.; Spichiger, U. E.; Simon, W. Anal. Chem. 1991, 63, 2285.

29. Meier, P. C.; Morf, W. E.; Läubli, M.; Simon, W.; Anal. Chim. Acta 1984, 1, 156.

30. Ammann, D.; Ion-Selective Microelectrodes, Springer: Berlin, 1986.

31. Daunert, S.; Wallace, S.; Florido, A.; Bachas, L. G.; Anal.Chem. 1991, 63, 1676.

32. Leyzerovich, N. N.; Shvedene, N. V.; Bilkova, Y. N.; Tomilova, L. G.; Pletnev, I. V.; Electroanalysis 2001, 3, 246.

33. Shahrokhian, S.; Amini, M. K.; Kia, R.; Tangestaninejad, S.; Anal. Chem. 2000, 72, 956.

34. Hutchins, R. S.; Bansal, P.; Molina, P.; Alajarin, M.; Vidal, A.; Bachas, L. G.; Anal.Chem. 1997, 69, 1273.

35. Xu, L.; Yuan, R.; Fu, Y. Z.; Chai, Y. Q.; Anal. Sci. 2005, 21, 287. 